\title{
A NEW SPECIES OF MARINE SPIDER DESIS FROM JAPAN
}

$\operatorname{AUTHOR}(\mathrm{S})$ :

Yaginuma, Takeo

CITATION:

Yaginuma, Takeo. A NEW SPECIES OF MARINE SPIDER DESIS FROM JAPAN. PUBLICATIONS OF THE SETO MARINE BIOLOGICAL LABORATORY 1956, 5(3): 363-366

\section{ISSUE DATE:}

1956-12-20

URL:

http://hdl.handle.net/2433/174565

RIGHT: 


\title{
A NEW SPECIES OF MARINE SPIDER DESIS FROM JAPAN ${ }^{1>}$
}

\author{
TAKEO YAGINUMA \\ Biological Laboratory, Otemon Gakuin, Osaka
}

With 5 Text-figures

It has been reported in some papers that the marine spider called only as "Desis sp." has occasionally been found in Japan. To date, however, as far as the author is aware, neither a specific description nor a correct identification of it, has yet been made.

Recently the author had an opportunity to study Japanese marine spiders Desis which were obtained at Shirahama, Prov. Kii, by Dr. H. Utinomi (Seto Marine Biological Laboratory) and at Tokara Islands, south of Kyushu, by Mr. S. UÉNo (Kyoto University).

Marine spiders Desis spp. have been found in the tropical and temperate zones of Eastern hemisphere, particularly in the southern part. From the point of their distribution, it is very interesting to know that they are found in Japan, which probably forms the northern limit of their habitat.

The author examined three individuals, of which one is an adult male, and the other two subadult females. As the result of careful comparison (of the arrangement of eyes, teeth of fang furrow and the other characteristics of the main parts of the body) they are found to belong to the same species, although they were collected from different parts of Japan.

The genus Desis was established by WALCKEnAer in 1837, and afterwards some related genera, Dandridgia, Robsonia and Paradesis were created by some arachnologists, but further investigations by SIMON and POCOCK proved these genera to be Desis. The result of the author's investigation determined the present specimens as a new species of Desis.

The author wishes to express his hearty thanks to Dr. H. UTinomi, Mr. S. Uéno and Mr. Y. Tsursui (The leader of the Scientific Survey of the Tokara Islands, and Director of the Osaka Municipal Museum of Natural History) for their kindness in giving him an opportunity to study the materials they collected, and also to Dr. T. EsAKI (Kyushu University), Mr. T. HABE (Kyoto University) and Miss C. OKuma (Kyushu University) for presenting the author with references.

1) Contributions from the Seto Marine Biological Laboratory, No. 285.

Publ. Seto Mar. Biol. Lab., V (3), 1956. (Article 22) 


\section{Desis japonica sp. nov.}

Japanese name: Yamato-Ushiogumo

Cephalothorax elongated, longer than first femur, or the combined length of patella and tibia of first leg, square in front, slightly rounded on both sides of thorax. Median furrow short and longitudinal. Cervical groove and radial furrows shallow but distinct. Eyes in two rows. The breadth of eye area one half of that of head. Anterior row of eyes almost straight, posterior row slightly recurved. Posterior row of eyes a little longer than anterior. Anterior median eyes separated from each other
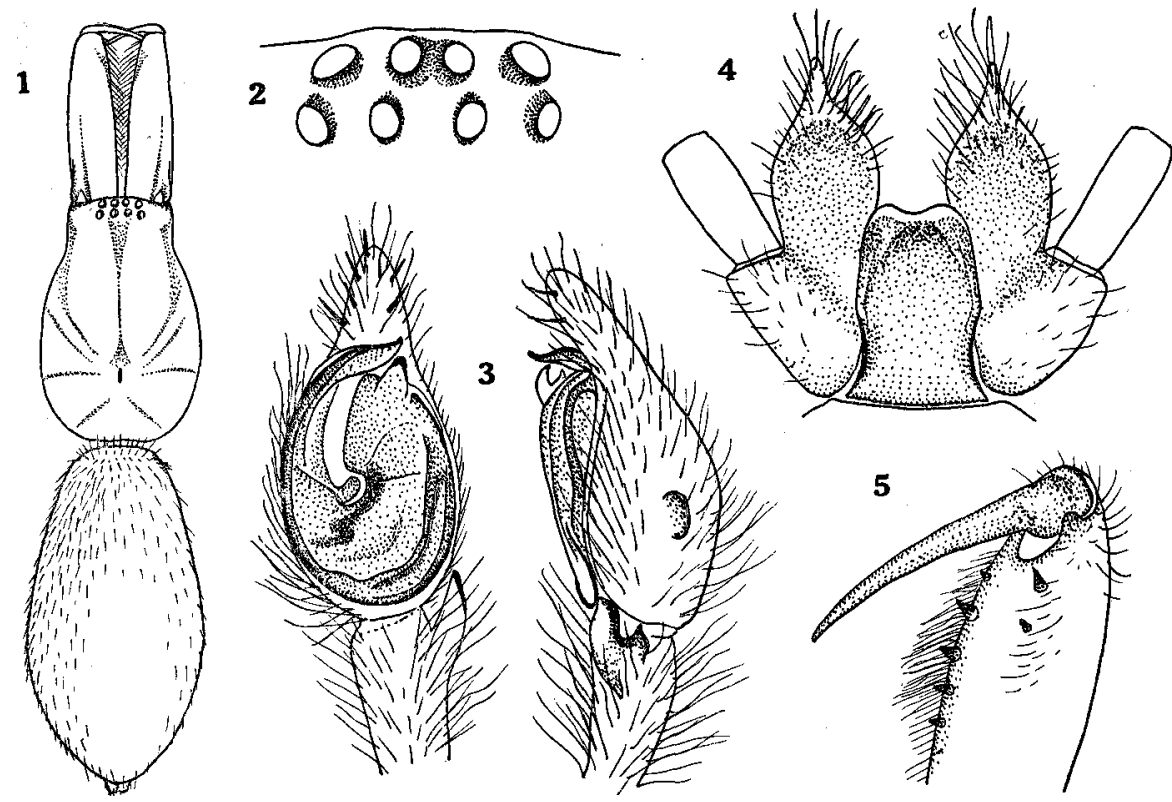

Desis japonica sp. nov.

Fig. 1. Dorsal aspect, legs omitted.

Fig. 2. Eye area.

Eig. 3. Male palp.

Fig. 4. Endites and labium.

Fig. 5. Chelicera.

by less than their own diameter, and from laterals by their own diameter; posterior medians about twice their diameter apart and the distance to laterals 1.5 times their diameter. Median eye area narrower in front than behind. Anterior lateral eyes somewhat larger than posterior laterals. Distance between laterals about one half of the diameter of anterior laterals.

Clypeus very long, projected nearly straight forward, but slightly shorter than the length of carapace, their ratio being about $4: 5$. Chelicera with lateral condyle much hairy at inner side, promargin of fang furrow with seven teeth, their distal small and slightly farther from the base of fang than from the adjacent tooth, the 
second, largest of all, and the rest gradually diminishing to the proximal, retromargin with two teeth near the base of fang, of which the distal large, and situated equally from both fang base and the other tooth. Endite long, pointed apically, with long scopulae, inner side parallel. Labium much longer than wide, slightly narrowing anteriorly, extend beyond the middle of endite, slightly depressed at its extremity. Sternum oval and flat with concave emarginations opposite coxae. Legs 1, 4, 2, 3, with scopulas beneath metatarsus of legs 2,3 , 4, each leg with two bristles on femur, the other legs with weak spines as shown in the following table.

\begin{tabular}{|c|c|c|c|c|c|c|c|c|c|c|}
\hline \multicolumn{2}{|c|}{ Legs } & Fem. & \multirow{2}{*}{ Pat. } & \multirow[t]{2}{*}{ Tib. } & \multicolumn{3}{|c|}{ Metatar. } & \multicolumn{3}{|c|}{ Tar. } \\
\hline I & $\begin{array}{l}\mathrm{d} \\
\mathrm{v}\end{array}$ & ${ }^{1}$ (Bristle) & & & & & & & & \\
\hline II & $\begin{array}{l}\mathrm{d} \\
\mathrm{v}\end{array}$ & $(1,1)$ & & & & 2 & & & & \\
\hline III & $\begin{array}{l}\mathrm{d} \\
\mathrm{v}\end{array}$ & $\begin{array}{lll}1 & & 1 \\
( & \prime & )\end{array}$ & & $\begin{array}{l}1 \\
1\end{array}$ & 2 & $\begin{array}{l}2 \\
2\end{array}$ & & 2 & 2 & 2 \\
\hline IV & $\begin{array}{l}\mathrm{d} \\
\mathrm{v}\end{array}$ & $\left.\begin{array}{lll}1 & & 1 \\
( & & 1\end{array}\right)$ & & 2 & 2 & $\begin{array}{l}2 \\
2\end{array}$ & 2 & 2 & 3 & 2 \\
\hline
\end{tabular}

Male palpus long, with bifurcated process on outer side of its tibia. Extremity of palpus with several short stout spines. Embolus running along $3 / 4$ of the circumference of palpus, with its tip bent.

Colour: Carapace reddish brown, deeper anteriorly, especially so at the corners of the head and appear blackish brown. Chelicerae of the same colour as carapace, but fang deep brown. Labium and endites also reddish brown with white tip. Legs yellowish brown but the coxae of 1st legs deep brown. Sternum brown, deeper around the circumference. Abdomen yellow, covered with grey hairs, venter lighter than dorsum.

Measurements : (mm)

Total length (excluding the chelicera) 6.1

$\begin{array}{lll}\text { Carapace } & 3.0 & \text { Abdomen }\end{array}$

Chelicera $\quad 2.3$

\begin{tabular}{c|c|c|c|c|c}
\hline \hline Legs & Fem. & Pat. \& Tib. & Met. & Tar. & (excluding Coxa \& Troch.) \\
\hline 1 & 2.4 & 3.6 & 2.8 & 1.6 & 10.1 \\
2 & 1.5 & 2.5 & 1.2 & 1.0 & 6.7 \\
3 & 1.2 & 1.8 & 1.5 & 0.9 & 5.2 \\
4 & 2.1 & 2.9 & 2.4 & 0.9 & 7.9 \\
\hline
\end{tabular}




\section{Localities and Date:}

Shirahama beach (Kii Peninsula) September 1954

t adult (collected by Dr. H. UTINOMI)-Holotype- -

Takarazima (Tokara Islands) June 1955

2 우 so subadult (collected by Mr. S. UéNo)

Holotype (S.M.B.L. Type No. 162) is preserved in the collection of the Seto Marine Biological Laboratory.

Remarks: The present species is nearly allied to Desis marina (HECTOR), collected in New Zealand, Australia and New Caledonia, in general appearance, but it may be distinguished from the latter in the arrangement of eyes, the relative position of marginal teeth of fang furrow, and the form of embolus which has its extremity bent. Noteworthy characteristics distinguishing this species from other Desis are that the posterior median eyes are farther from each other than to the laterals, and that the chelicera is shorter than the cephalothorax.

\section{REFERENCES}

BERL.AND, L. 1932. Les Arachnides, pp. 132-134.

Cambridge, O. P. 1879. Proc. Zool. Soc. London, p. 686.

1890. Proc. Zool. Soc. London, p. 625.

Chamberlain, G. 1947. Rec. Auckland Inst. Mus., vol. 3, p. 158.

EsAKI, T. 1930. Myriapoda and Arachnida (in Japanese), pp. 46-47. 1934. Zoological Dictionary (in Japanese), p. 339.

HECTOR, 1877. Trans. N. Zealand Inst., vol. 10, p. 300.

Kishidd, K. 1921. Zool. Mag. (in Japanese), vol. 33, no. 390, p. 135.

*Koch, L. 1872. Die Arach. Austral.

MARPles, B. J. 1955. Journ. Linn. Soc. Zool., vol. 42, no. 287, p. 502.

Mc. KEown, K. C. 1952. Australian spiders, p. 169.

Ohshima, H. 1930 . Zool. Mag. (in Japanese), vol. 42, no. 494, pp. 35-36.

Pocock, R. I. 1902. Proc. Zool. Soc. London, pp. 98-106.

*-1895. Ann. Mag. Nat. Hist., vol. 16.

Powell, 1879. Trans. N. Zealand Inst., vol. 11, pp. 263-268.

RaInbow, W. J. 1912. Rec. Aust. Mus., vol. 9, no. 2, p. 258.

SAKAGUCHI, S. 1931. Lansania (in Japanese), vol. 3, no. 23, pp. 33-35.

SAVORY, T. H. 1928. Biology of spiders, pp. 197-198.

Simon, E. 1898. Hist. Nat. Araig., vol. 2, pp. 225-228.

THORELL, T. 1890-73. Rem. Syn. Europ. Spid., p. 75.

White, A. 1849. Proc. Zool. Soc. London, p. 5.

*WorkmaN, T. G. 1896. Malaysian spiders.

(* not directly referred.) 